\title{
Comparative Study of Nirmalya Solid Waste Treatment by Vermicomposting and Artificial Aeration Composting
}

\author{
PALLAVI S. CHAKOLE* and D.B. JASUTKAR \\ Department of Civil Engineering, G.H. Raisoni College of Engineering, Nagpur- 440016, India. \\ http://dx.doi.org/10.12944/CWE.9.2.23 \\ (Received: May 13, 2014; Accepted: June 20, 2014)

\begin{abstract}
Temple waste normally contains floral offering, leaves and milk product i.e. "Abishek waste water", and this solid waste management is one of the important issues in the world, because of shortage ofdumping sites and strict environmental legislation. Now days 'Nirmalyasolid waste' is generated in large quantity due toincreased in population are commonly treated using different types of bins by the method of composting or vermicomposting. Vermicomposting of solid waste can be done by using different types of earthworms providing natural and artificial aeration along with mixture of cow dung and soil, artificial aeration is carried out by providing diffused aerators or perforated pipes. The parameters like $\mathrm{C} / \mathrm{N}$ ratio, temperature, moisture contain are carried out. The main objective of this study is to minimize the problem of solid waste management by treating nirmalya solid waste by vermicomposting and suggesting that which method gives good quality of compost at short interval of time comparing artificial and natural aeration composting.
\end{abstract}

Key words: Nirmalya solid waste, Vermicomposting, artificial aeration.

\section{INTRODUCTION}

Solid waste and waste water was Collected from "Ganesh Tekadi temple" Nagpur. Generally $500 \mathrm{~kg}$ of nirmalya solid waste containingfloral offering, leavesand 200 to 300 lit of "Abishek waste water" which contain milk, sugar and milk products are generate daily at 'Ganesh Tekadi'. Generated nirmalya waste is collected in bin and transferred to the collection point; from that point waste is collected by NMC vehicles and transferred to the treatment plant.

Solid waste is basically unwanted or discarded material that is not a liquid or a gas; it can include organic waste, paper, metals, glass, cloth, brick and rock, yard waste etc.Now a daysdue to increased in population number of temples are developed and tons of temple waste in the form of flowers, leaves, fruits, sugar, milk and milk products, grains generated daily are disposed in open dumps or river generating foul odor as well as act as breeding centers for disease causingmicroorganism. Looking into the hazardous impact of the improper disposalof wastes on the environment, emphasis should be given on aerobiccomposting which converts waste into organic manure rich in plant nutrients, common treatment provided for these waste are Composting and vermicomposting.

To minimize health hazards and environmental problem the method of composting is done by making a heap of wetted organic matter (leaves, "green" food waste) and waiting for the materials to break down into humus after a period of weeks or months. Inmodern technique composting is a multistep, closely monitored process with measured inputs of water, air, and carbon and nitrogen rich materials, the decomposition process is aided by shredding the plant matter,adding water and ensuring proper aeration by regularly turning the mixture.

Now a day's growing interest in vermicomposting of this waste as it adds value to waste, and furthermore reduces the volume to make 
its application easier. Municipal solid waste is highly organic in nature; therefore vermicomposting of MSW has become a suitable option for the safe, hygienic and cost effective disposal. Vermicomposting is known as a sustainable source of macro and micronutrients, plant growth hormones and enzymes (Kale and Karmegam, 2010) which not only enhancemicrobial population but also hold nutrients for longer periods(Ndegwa and Thompson,2001). Becauseofthesebeneficial properties vermicompost can be directly applied to soil to increased soil structure and its capacity by using different species of earthworms i.e. Eisenia fetida or Eisenia andrei,Eisenia hortensis or Dendrobaena veneta. Vermicomposting is the method which, recyclesthe crop residues and significantly increases theamount of $\mathrm{N}, \mathrm{P}$ and $\mathrm{K}$ concentration in compost. The important role ofearthworms in ecosystem is in nutrient recycling,particularly nitrogen. Thus, they affect the physicochemicalproperties of soil.

The action of earthworms in the process of vermicompostingof waste is physical and biochemical. Thephysical process includes substrate aeration, mixing aswell as actual grinding while the biochemical process isinfluenced by microbial decomposition of substrate inthe intestine of earthworms. Variousstudies have shown that vermicomposting of organicwaste accelerates organic matter stabilization. Vermicomposting is carried out for three types of waste i.e. kitchen waste, farmyard waste and temple waste for period of 120 day for suggesting good compost for seed germination and plant growth, after analysis of $\mathrm{C} / \mathrm{N}$, TK, conductivity, resulted that temple waste using Eisenia fetida is good as compared to other two waste (Akanksha Singh et.al., 2013).

\section{MATERIALS AND METHODS}

\section{Solid waste}

Solid waste basically contains paper, plastic, food, yard waste, flower, leaves etc. Out of these "Nirmalya waste" is used in present study, it mainly consist of different types of floral offering and leaves. The nirmalya waste was collected from "Ganesh Tekadi" Nagpur.Generally $500 \mathrm{~kg}$ of nirmalya waste are generated daily. In this study total $6400 \mathrm{gm}$ waste was collected and divided into two bins containing $3200 \mathrm{gm}$ of nirmalya waste in each bin. Initial analysis of that solid waste was carried out. $\mathrm{pH}$ of solid waste was checked by $\mathrm{pH}$ meter; moisture content was calculated by oven dry method and density of that solid waste.

\section{Waste water}

"Abishek waste water" was collected from Ganesh tekadi temple. Basically 200 to 300 lit of waste water were generated daily, to check quality of that water initial analysis was carried out. Total three samples were collected at two day interval and chemical characterization of that abishek water was carried out. Parameter tested is $\mathrm{pH}$, chemical oxygen demand (COD) and hardness. $\mathrm{pH}$ was checked by $\mathrm{pH}$ meter, COD by COD digester and hardness with simple titration method. Each sample was analyzed thrice to get accurate results.

\section{Composting}

After the analysis of nirmalya waste, actual setup was prepared using two plastic bins with dimensions measuring $50 \mathrm{~cm} \times 28 \mathrm{~cm}$, were used for composting having natural holes, out of two bins one having natural aeration and other having artificial aeration provided by perforated pipe, inlet

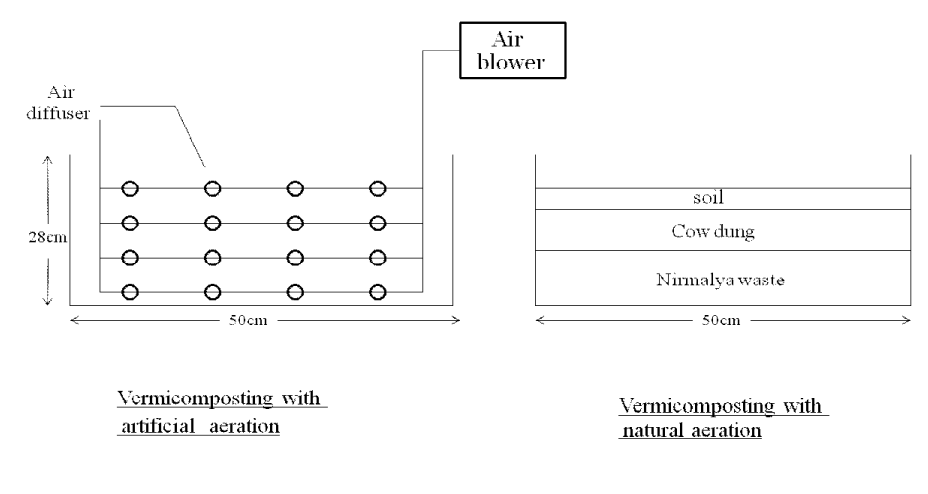

Fig. 1: Layout of composting bin 
end of the pipe is closed and outlet it connect to air blower. Bins contain nirmalya waste along with cow dung arranged in alternate layer and finally covered with layer of soil. It consists of total $5000 \mathrm{gm}$ waste containing (3200 gm nirmalya waste +1500 gm cow dung $+300 \mathrm{gm}$ soil). After feeding all the material in each bin, initially analysis of moisture content was

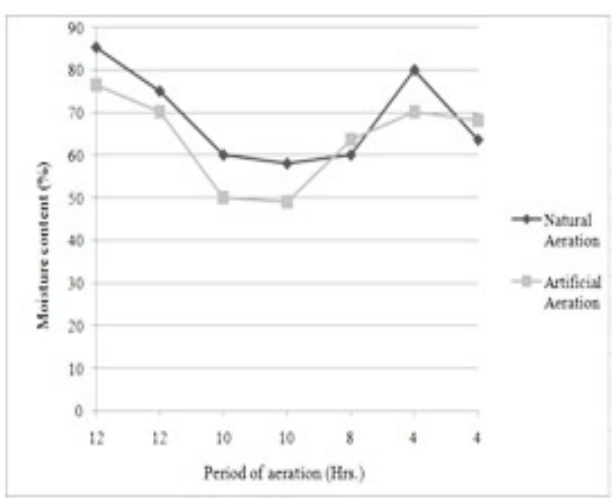

Fig. 2: Comparison between Artificial and Natural aeration composting

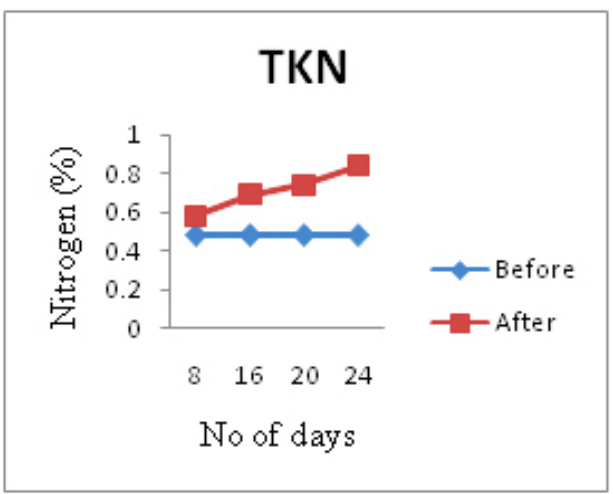

Fig. 3(a): Line chart for TKN for NAC

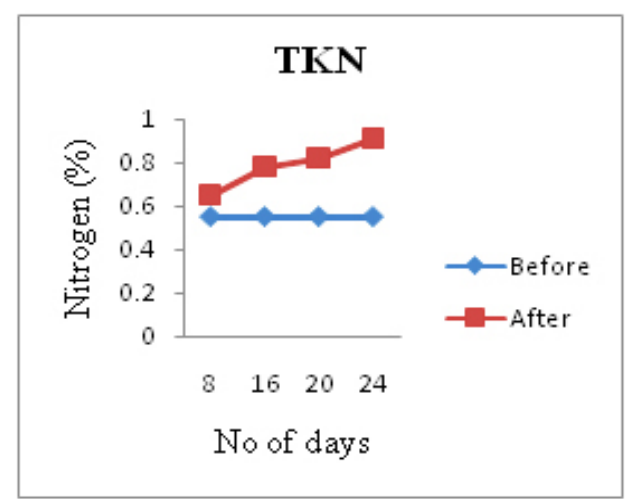

Fig. 3 (c): Line chart for TKN for AAC carried out at periodic interval of time. Moisture content was calculated daily to maintained the value up to $60 \%$ throughout the composting period by oven dry method, if it increases above $60 \%$ then it reduced by sprinkling of water. Analysis was carried out after

Table 1: Abishek waste water" analysis

\begin{tabular}{lccc}
\hline Parameters & Sample1 & Sample 2 & Sample3 \\
\hline $\mathrm{pH}$ & 6.51 & 6.36 & 6.71 \\
$\mathrm{COD}(\mathrm{mg} / \mathrm{lit})$ & 616 & 628 & 600 \\
Hardness (mg/lit) & 140 & 120 & 124
\end{tabular}

Table 2: "Nirmalya waste" was collected from Ganesh temple analysis

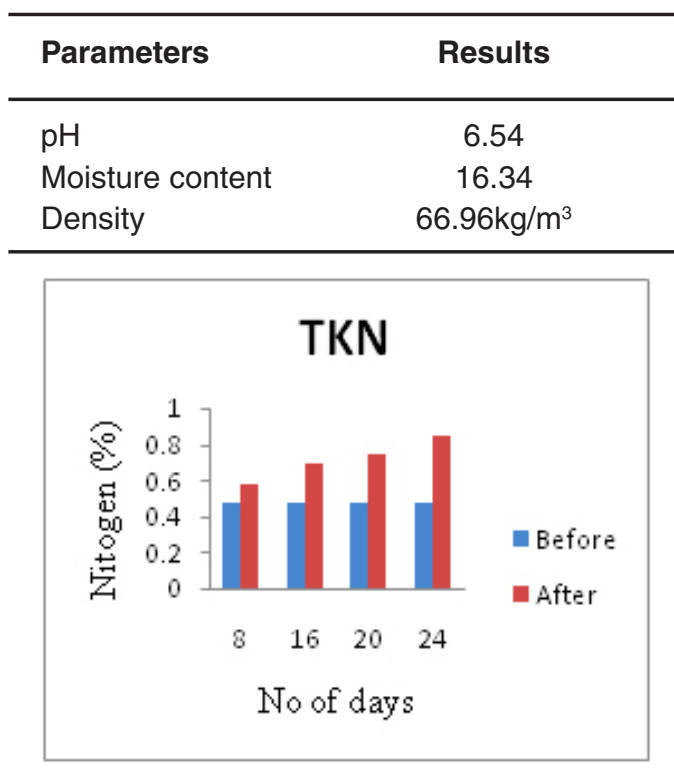

Fig. 3 (b): Bar chart for TKN for NAC

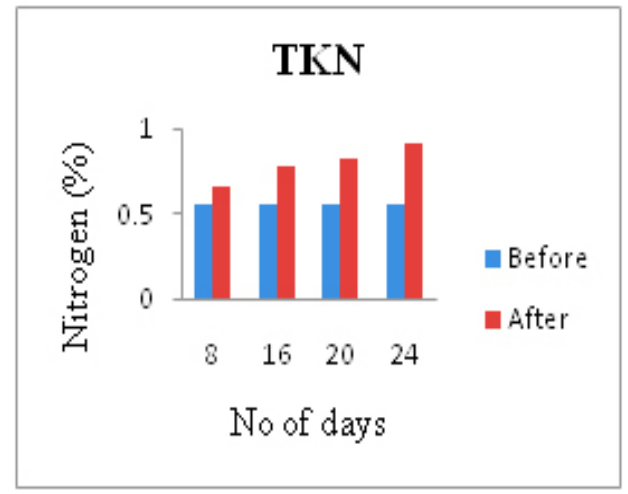

Fig. 3 (d): Bar chart for TKN for AAC

Fig. 3Variation of nitrogen content before and after composting 
45 to 60 day of composting period. Parameter tested was temperature by thermometer on daily basis, carbon content by muffle furnace and nitrogen was analyzed by Kjeldhal method.

\section{Earthworms}

Adult clitellate worms, Eisenia fetida, ranging in length from 4 to $8 \mathrm{~cm}$ was collected from "Gorakshan Kendra" wardha road, Nagpur. Total quantity of 25 to 30 no were added in each bin through the developed cracks after 60 to 65 days of partial decomposition of waste. After the addition of earthworm analysis was carried out at specific interval of time to check the degree of organic waste stabilization. Earthworms species i.e. Eisenia fetida (Red worms) are used in the present study.

\section{Vermicomposting}

It is the process of decomposition of organic waste matter using earthworms. In this work earthworms species i.e. Eisenia fetida is used

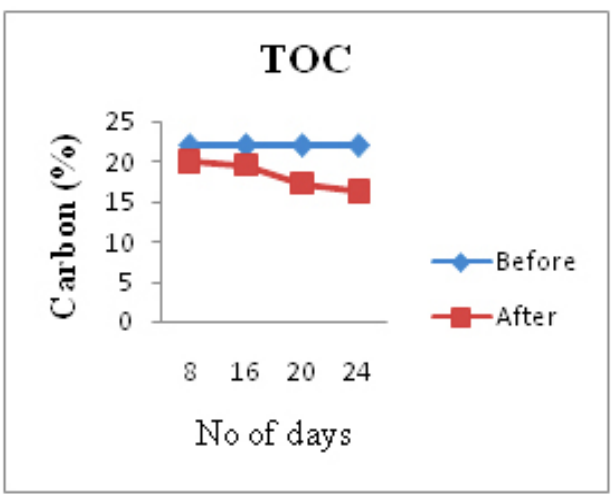

Fig. 4 (a) Line chart for TOC for NAC

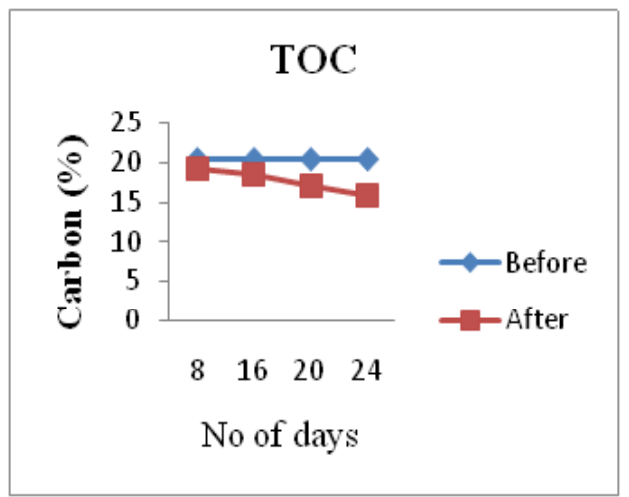

Fig. 4 (c) Line chart for TOC for AAC as compost is use as instant source of food to the earthworms. After the addition of earthworms physicochemical characterization of waste was carried out at specific interval of time. Important parameter required to check the stabilization of waste are Total Kjeldhal nitrogen (TKN), Total organic carbon (TOC), $\mathrm{C} / \mathrm{N}$ ratio and $\mathrm{pH}$. To prevent wormsfrom the thermophilic reaction occurring during composting watering wasstopped when the VC was ready as indicated by uniform dark brownto black colour granular structure. Three days later the compostalong with worms was harvested and the worms were removed by sieving. The number of adult worms separated wasweighed.

\section{RESULTS AND DISCUSSION}

\section{Waste water}

"Abishek waste water" analysis was carried out showing results in Table 1.

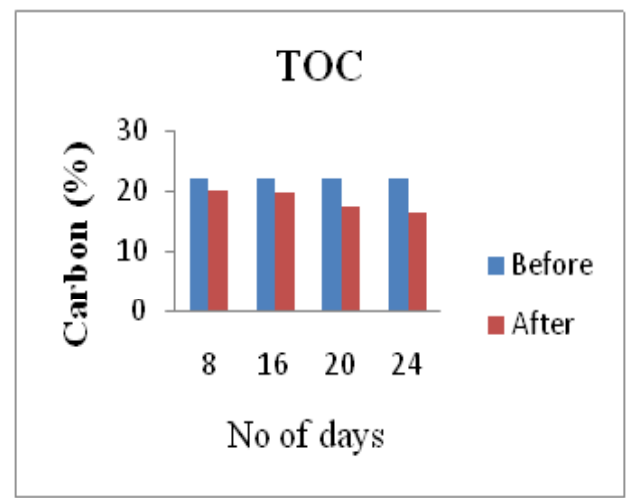

Fig. 4 (b) Bar chart for TOC for NAC

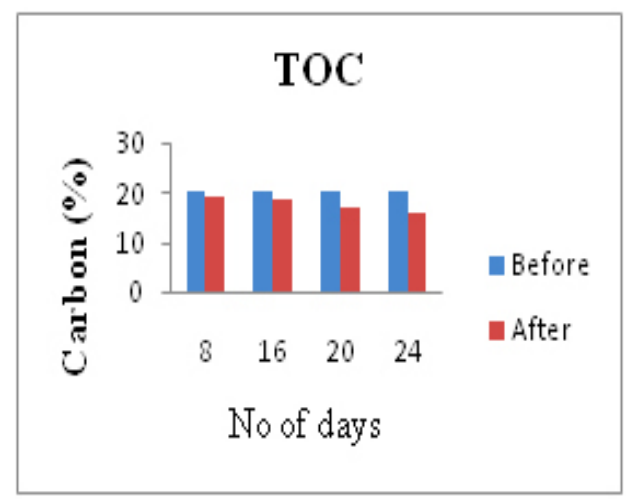

Fig. 4 (d) Bar chart for TOC for AAC

Fig. 4:Variation of carbon content before and after composting 


\section{Solid waste}

"Nirmalya waste" was collected from Ganesh temple and initial analysis of that waste was carried out. Parameter checked was $\mathrm{pH}$, moisture content and density of solid waste. Results are shown in table 2.

Analysis of moisture content and temperature providing natural and artificial aeration

After the stabilization of actual setup continuous analysis of temperature and moisture content by using natural aeration and artificial aeration with specific interval of time was carried out, to maintained the moisture content about $60 \%$ to $70 \%$ by increasing or decreasing the period of aeration and by continuous sprinkling of water because for the process of composting not much more moisture is required it is always in controlled range. Comparative results of natural and artificial aeration are shown in Fig.2.

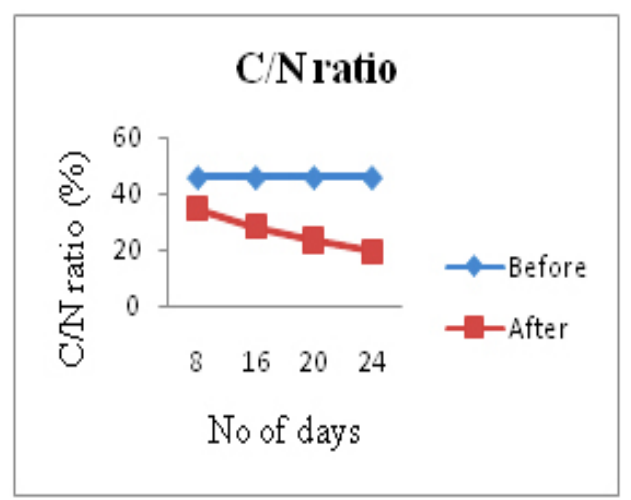

Fig. 5 (a) Line chart for $\mathrm{C} / \mathrm{N}$ ratio for NAC

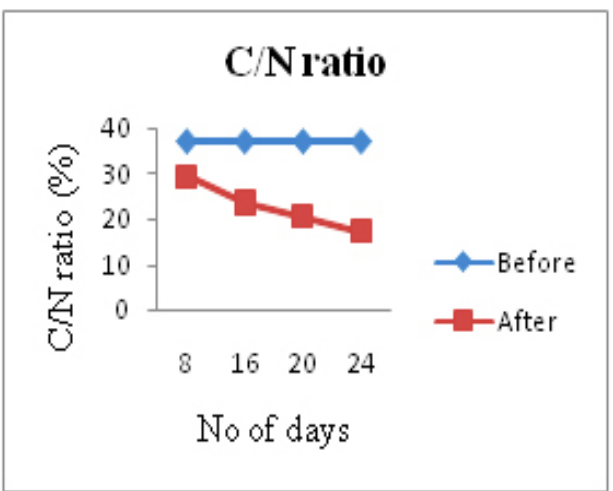

Fig. 5 (c) Line chart for $\mathrm{C} / \mathrm{N}$ ratio for $\mathrm{AAC}$
From the above graph it is shows that artificial aeration gives less moisture content as compared to natural aeration and it help to maintained moisture to desired level.Composting proceeds best at a moisture content of $40-60 \%$ by weight. At lower moisture levels, microbial activity is limited. At higher levels, the process is likely to become anaerobic and foul smelling. When theand mixing of compost ingredients, measure the moisture content.After the composting is underway, don't need to repeat this measurement because you can observe whether appropriate moisture levels are being maintained.

\section{Compost and Vermicompost analysis}

The physicochemical properties of natural and artificial aeration composting was initially carried out parameter tested was $\mathrm{pH}, \mathrm{TOC}, \mathrm{TKN}$ and $\mathrm{C} / \mathrm{N}$ ration after the specific interval of time earthworms are added in the bin and same

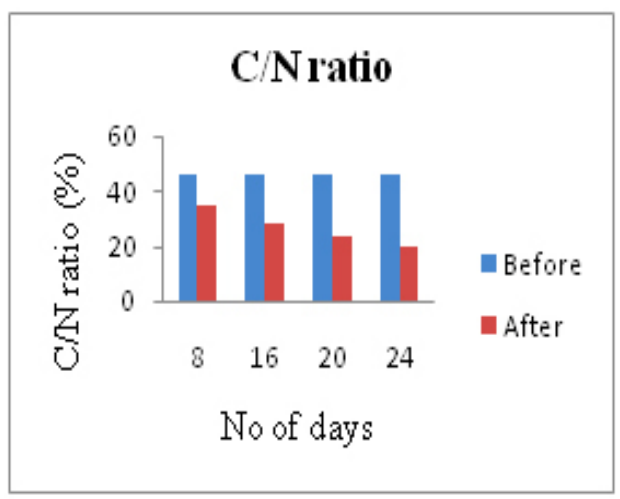

Fig. 5 (b) Bar chart for $\mathrm{C} / \mathrm{N}$ ratio for NAC

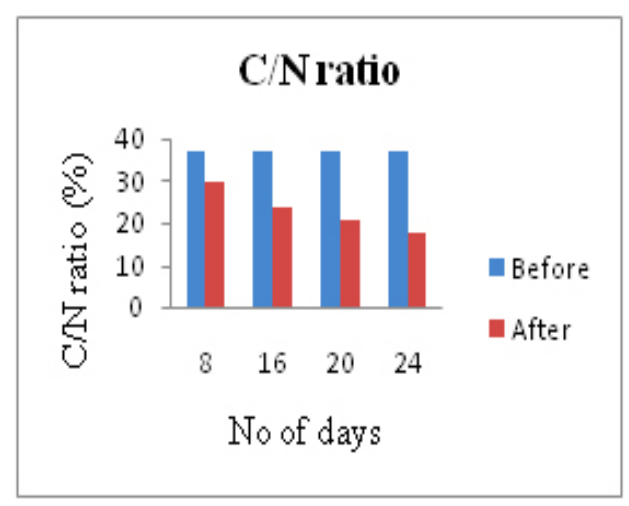

Fig. 5 (d) Bar chart for $\mathrm{C} / \mathrm{N}$ ratio for $\mathrm{AAC}$

Fig. 5: Variation of $\mathrm{C} / \mathrm{N}$ ratio before and after composting 
chemical characteristic was carried out which shows significant variation in $\mathrm{pH}, \mathrm{TOC}, \mathrm{TKN}$ and $\mathrm{C} / \mathrm{N}$ ration before and after the vermicomposting.

Comparison of physicochemical characteristic before and after composting inboth the method by natural and artificial aeration

From the above graph of natural aeration composting shows that initial nitrogen content was very low i.e. 0.48 as compared to this when earthworms are added it accelerate the process of composting and increased the nitrogen content in both the bin but maximum result is obtained in artificial aeration composting. The increase in total nitrogen content was higher in vermicompost than composts, where cow dung increment resulted in increased nutrient contents. Many authors reported that losses in organic carbon might be responsible for nitrogen upgrading

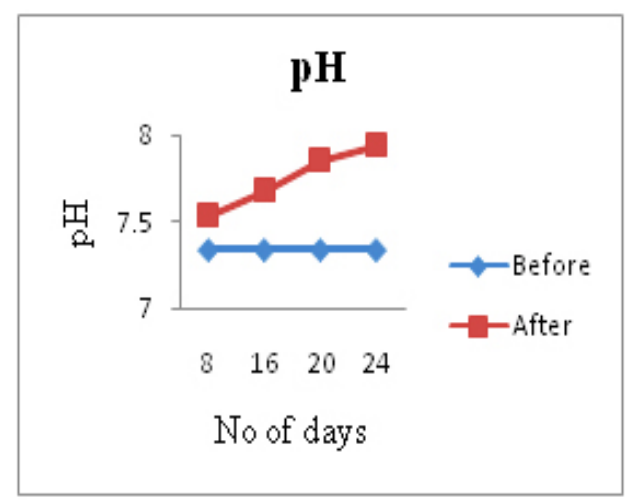

Fig. 6 (a) Line chart for $\mathrm{pH}$ for NAC

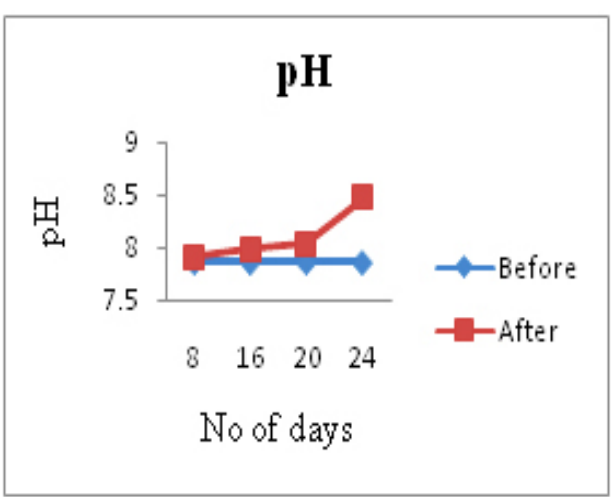

Fig. 6 (c) Line chart for $\mathrm{pH}$ for AAC
As the result shows that initially carbon was very high in natural as well as artificial aeration composting i.e. 22.04 and 20.45 due to low concentration of nitrogen as the process of composting proceeds carbon content get decreased to value of 15.82 for artificial aeration composting which is good for compost as compared to this 16.34 for natural aeration composting with same interval of time. The microbial respiration may lead to rapid carbon loss throughCO $\mathrm{CO}_{2}$ production and also, digestion of carbohydrates, lignin, celluloseand other polysaccharides from the substrates by inoculatedearthworms may cause carbon reduction during the decompositionof organic waste.

In the present study to reducethe $\mathrm{C} / \mathrm{N}$ ratio by minimal incorporation of cow dung, which is a goodsource of nitrogen, in order to make the waste mixture suitable fordecomposition using earthworms. The $\mathrm{C} / \mathrm{N}$ ratio of the composts in natural and artificial

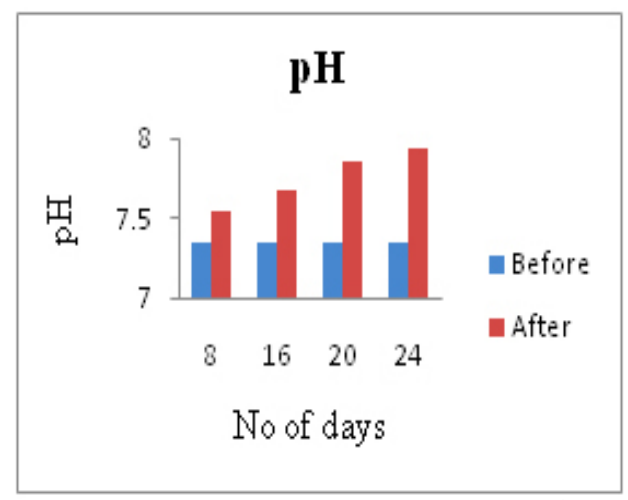

Fig. 6 (b) Bar chart for pH for NAC

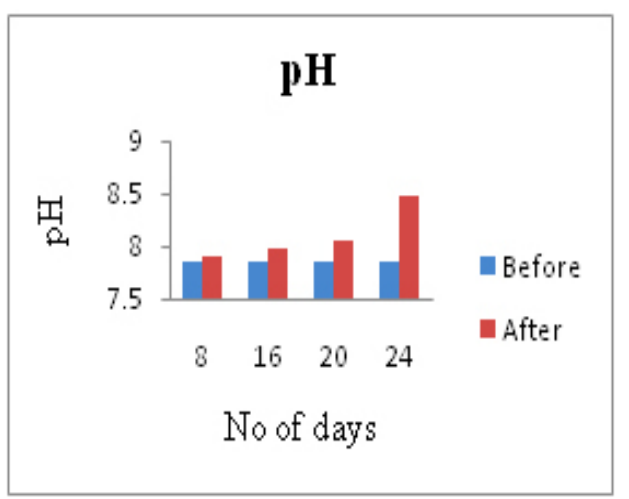

Fig. 6 (d) Bar chart for pH for AAC

Fig. 6: Variation of pH before and after composting 
aeration decreased continuously, initially ratio was 45.91 and after composting it is 19.45 in natural aeration compost bin in spite of this in artificial aeration compost bin it is decreased from 37.18 to 17.38 after the addition of earthworm as the same interval of time All final $\mathrm{C} / \mathrm{N}$ values were less than 20 , which illustrated that theorganic wastes had been stabilized.

As it is seen that the $\mathrm{pH}$ of initial compost was low in both the bin as compared to this $\mathrm{pH}$ was increased after the addition of earthworms in bin. $\mathrm{pH}$ in artificial aeration composting is more i.e. 8.48 as compared to 7.94 in natural aeration bin. It wasreported by Kadam, 2004 that minimum biomassand cocoon production was obtained at $\mathrm{pH}$ 5 and 9 while earthworms were killed at $\mathrm{pH}$ below 5 andabove 9 and maximum biomass and cocoon production of $E$. fetida was obtained and make the process of composting faster.

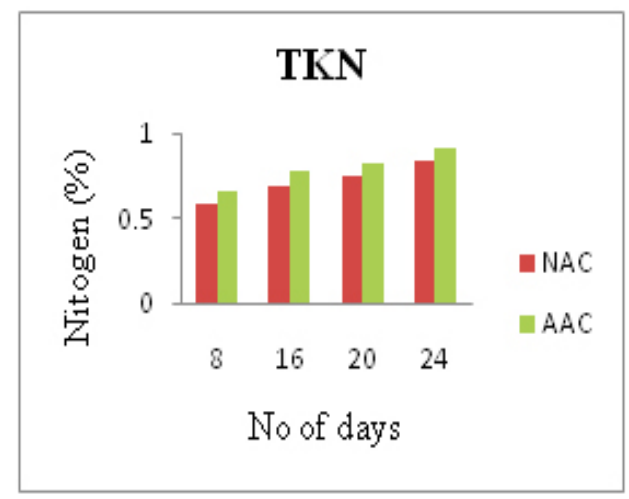

Fig. 7 (a): Line chart for TKN
Comparison of physicochemical characteristic of compost between natural and artificial aeration composting

Total Kjeldhal nitrogen content of the compost increased significantly with time in both the bin of natural and artificial aeration composting inthe presence of earthworms. As in the initial phase value of nitrogen content was 0.48 and it is increases in both the method of composting but higher value obtained as 0.91 in artificial aeration composting as compared to natural aeration i.e. 0.84 at the end of vermicomposting periodin different feed mixtures, probably due to mineralizationof the organic matter.

From above graph it is clear that total organic carbon content providing artificial aeration is less as compared to natural aeration due to increased amount of nitrogen. As the carbon content

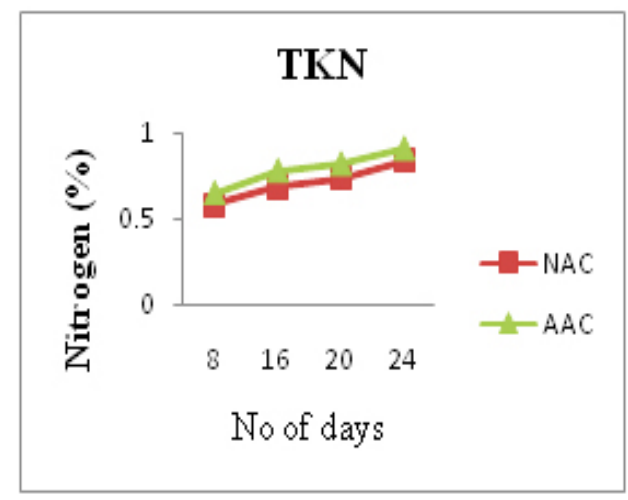

Fig. 7(b): Bar chart for TKN

Fig. 7: Comparison of nitrogen content between natural and artificial aeration Composting

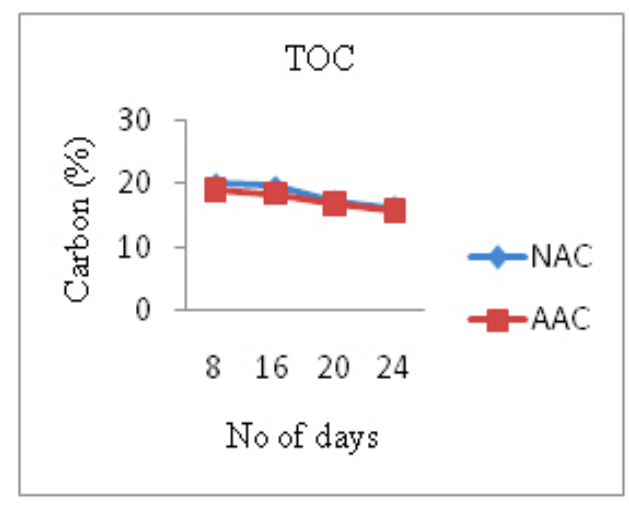

Fig. 8 (a): Line chart for TOC

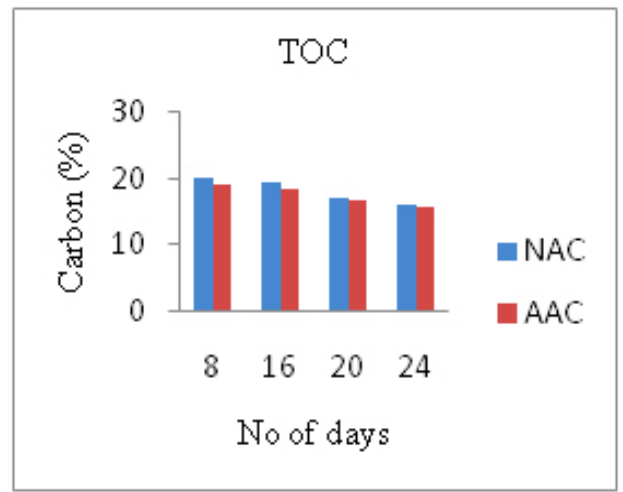

Fig. 8 (b): Bar chart for TOC

Fig. 8: Comparison of carbon content between natural and artificial aeration composting 
in natural aeration composting is more 16.32 as compared to artificial aeration composting i.e. 15.82 which is good for compost and shows faster rate of decomposition of waste

The best and pronounced results were obtained from artificial aeration vermicomposting as it gives the value of $\mathrm{C} / \mathrm{N}$ ratio is less as compared to natural aeration and the lowest $\mathrm{C} / \mathrm{N}$ ratio in temple waste depicts faster rate ofdecomposition. Lowering of $\mathrm{C} / \mathrm{N}$ ratio is mainly caused due to release of part of the carbon as carbon dioxide $\left(\mathrm{CO}_{2}\right)$ due to respiratoryactivity of earthworms. Although comparison between two method of composting, artificial aeration composting give lower $\mathrm{C} / \mathrm{N}$ ratio i.e. 17.38 as compared to natural aeration with same interval of time. Hence, $\mathrm{C} / \mathrm{N}$ ratio less than 20 indicates better degree of organic matter stabilization and reflects a satisfactory degree of maturity of organic waste, the $\mathrm{pH}$ of both the method were

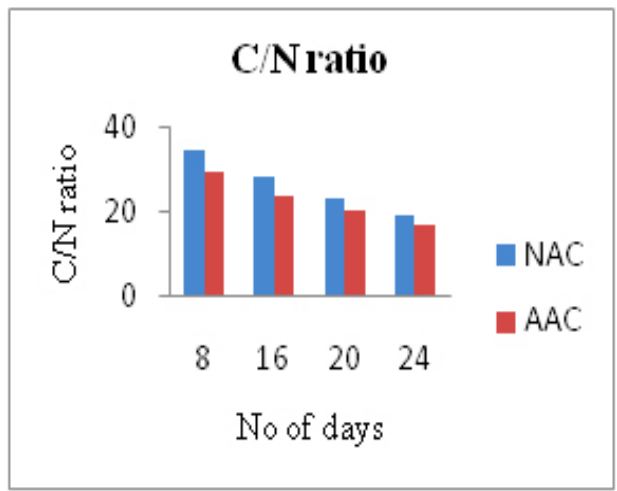

Fig. 9 (a): Line chart for $\mathrm{C} / \mathrm{N}$ ratio slightly acidicbut the final $\mathrm{pH}$ of all the two mature vermicompost was in the neutral range i.e. 7.90 to 8.48, highly favourable for worms whichare reported to survive in $\mathrm{pH}$ range 5-9. The $\mathrm{pH}$ of $\mathrm{VC}$ is reported to be substrate dependent and earthworms maintain the $\mathrm{pH}$ of vermicompost in the neutral range.The slightly basic nature of temple waste might be due to the formation of intermediate products during bioconversion of the organicwastes.

\section{CONCLUSION}

Evidencesfrom the present study revealed temple waste as a potential resourcematerial for Eisenia fetida biomass and nutrient rich homogeneous vermicompost production. Thus, from present study it can be conclude that nirmalya waste vermicomposting using artificial aeration in the form of perforated pipe along with natural as well as artificial aeration give good result at short

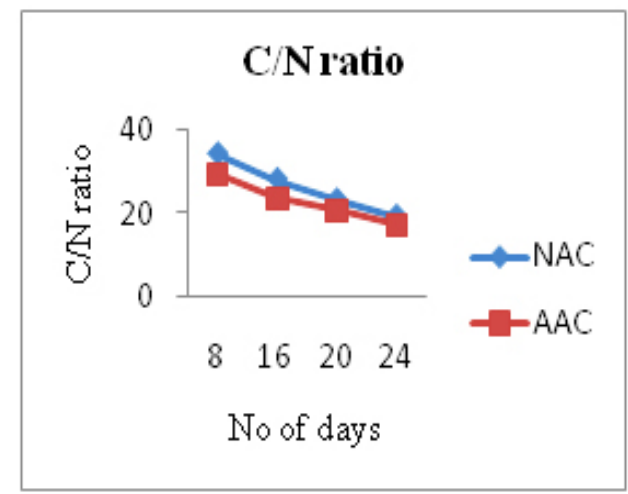

Fig. 9 (b): Bar chart for $\mathrm{C} / \mathrm{N}$ ratio

Fig. 9: Comparison of $\mathrm{C} / \mathrm{N}$ ratio between natural and artificial aeration composting

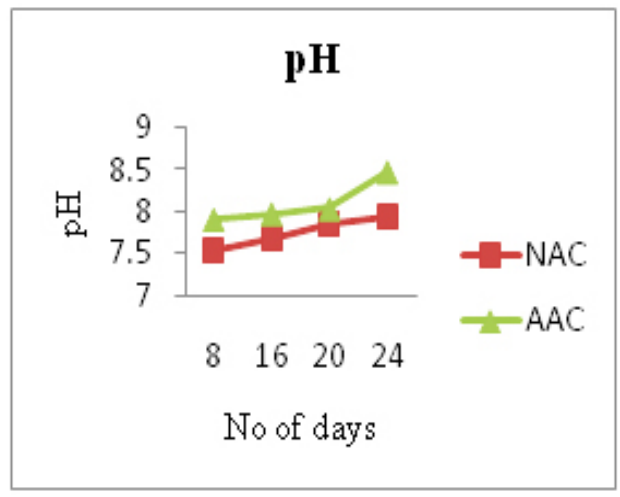

Fig. 10 (a): Line chart for pH

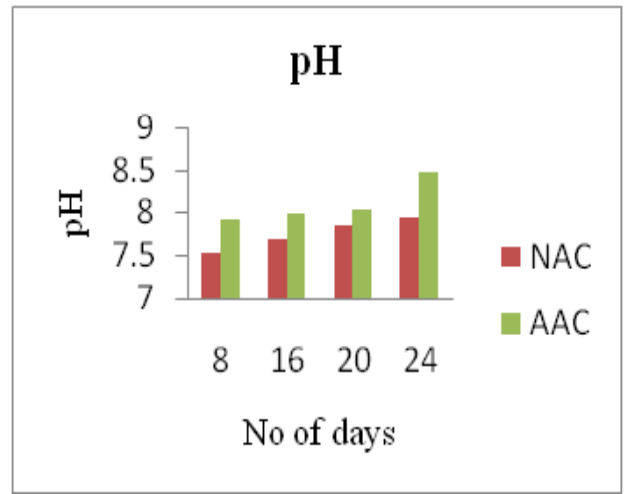

Fig. 10 (b): Bar chart for $\mathrm{pH}$

Fig. 10: Comparison of $\mathrm{pH}$ between natural and artificial aeration composting 
interval of time as compared to natural aeration vermicomposting is due to better physicochemical characteristic of compost obtained from artificial aeration vermicomposting. Nirmalya waste can therefore, be reuse in the form of compost and it also added value to the waste. Hence, nirmalya waste vermicomposting using artificial aeration is a good technique to minimize the problem of solid waste management at short interval and it can also be used as good quality of compost for plant growth, fertilizing and conditioning of land.

\section{ACKNOWLEDGMENT}

I would like to express my sincere respect and gratitude towards my guide his encouragement and constant support for study. Thepeople of Ganesh Tekadifor providing essential information and support. I would also like to thank the GHRCE laboratory and supportive staffs for providing essential chemicals and facilities and for the present work.

\section{REFERENCES}

1. Akanksha Singh et al., Waste management, 33: 1113-1118 (2013).

2. Kaleet al., N., Appl. Environ. Soil Sci. 56 41-43(2010).

3. Ndegwa, P.M. et al., Bioresource Technology, 76: 107-112 (2001).

4. Ademir S.F. Araujo, et al., Resources, Conservation and Recycling, 55: 719729(2011).

5. Gurav M. V. and Pathade G. R. Environmental Research and Technology,1: 182192(2011).

6. J.A.John Paul et al., Bioresource Technology, 10 : 6769-6773(2011).

7. Jaya Nair, et al.,Bioresource Technology, 97 : 2091-2095(2006).

8. Marina Himanen et al., Bioresource Technology, 102: 2842-2852(2011).

9. Payal Garg et al., Bioresource technology, 97:
391-395 (2006).

10. Q. Li, X. C. Wang, Bioresource tech-nology, 137: 270 - 277 (2013).

11. Robert et al., Bioresource Technology, 101: 6692-6698(2010).

12. Somjai Karnchana wong et al., Resources, Conservation and Recycling, 55: 548-553 (2011).

13. Singh, A. et al., Bioresource. Technology, 85: 107-111 (2002).

14. Subbiah. B.V et al., Bioresource. Technology, 25: 259-260 (1956).

15. Suthar, S., Ecol. Eng, 35: 914-920 (2009).

16. Ubeyde Ipek et al., Bioresource Technology, 84: 283-286 (2002).

17. Q. Li, X. C. Wang, Bioresource technology, 137: 270-277 (2013).

18. Payal Garg et al., Bioresource technology, 97 : 391-395 (2006). 